\title{
Preceitos de Clemente
}

\section{Precepts of Clement}

\section{Preceptos de Clemente}

\section{Cesar Motta Rios}

No presente trabalho, apresento uma tradução de Preceitos de Clemente. O texto, escrito em grego, foi encontrado na Biblioteca de El Escorial, nos arredores de Madrid, em um manuscrito contendo diversas passagens de diferentes teólogos. Ferguson reconhece como "conjectura razoável” o entendimento de que as palavras que ali se leem fossem oriundas de um tratado perdido de Clemente de Alexandria, que aparece mencionado por Eusébio de Cesareia (História Eclesiástica. 6.3) como Exortação à Perseverança on Aos recém-batizados (FERGUSON, 1974, p. 183). O conteúdo parece mesmo adequado a um tratado dessa natureza. Mas, ainda que não seja possível assegurar a obra de que os Preceitos de Clemente foram tomados, é certo que eles refletem bem o pensamento do mestre de Orígenes a respeito da vida cristã e que caberiam muito adequadamente no contexto da Escola de Alexandria. ${ }^{1}$

Uma leitura de $O$ Pedagogo de Clemente é suficiente para tornar evidente que a preocupação com detalhes da vida cotidiana, que se verifica no documento agora apresentado, não é estranha ao mestre alexandrino. Trata-se de uma concepção de moralidade em muito semelhante àquela de autores não cristãos do entorno cultural, mas adaptada à teologia cristã. Deus, como referência, muda a forma de se entender e de se dedicar à vida ética: "Não se trata mais do homem só; não é mais sua perfeição intrínseca, enquanto tal, que se busca:

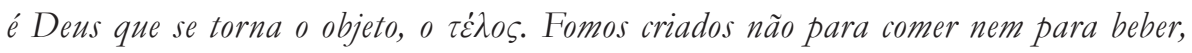
mas para conhecer a Deus" (MARROU, 1978, p. 198).

O texto grego que serve de base para a presente tradução encontra-se na edição da coleção Loeb, publicada pela Harvard University Press. Quando sigo a proposta de correção dos editores em um ou outro trecho, divergindo da lição do manuscrito, indico a opção em nota. Outras notas inseridas visam, ainda que limitadamente, contribuir para melhor compreensão do texto e reconhecimento de conexões importantes.

\footnotetext{
Não desconsidero, contudo, a possibilidade de que o documento seja resultado do esforço de um cristão da Antiguidade tardia, que tenha decidido resumir (a seu modo e, possivelmente, de memória) o ensino moral que lera na obra de Clemente.
} 


\section{Preceitos de Clemente ${ }^{2}$}

Pratica tanto a quietude nas palavras quanto a quietude nas ações. Ainda, de modo semelhante, no discurso e no caminhar. E foge dos impulsos sem controle. Pois, assim, a mente permanecerá firme, e não acontecerá de, tornando-se agitada pelo impulso, ser enfraquecida, limitada com respeito ao pensamento, ou de ter a visão obscurecida ${ }^{3}$. Também não dará lugar à gula, nem dará lugar à ira fervente, nem dará lugar às outras paixões, antepondo para elas uma presa previamente preparada. Pois é preciso que, elevada, assentada sobre um trono quieto, com a visão fixa em Deus, a mente prevaleça sobre as paixões.

Que não te lances por ira cheio de avidez por enraivecer-se, nem sejas enfadonho 4 nas palavras, ou cheio de hesitação no caminhar, para que um bom modo embeleze a tua quietude, e essa aparência manifeste algo sagrado e divino. E guarda-te também dos gestos de arrogância: aquela aparência de pescoço erguido, cabeça levantada, e passos de pés delicados e altivos. ${ }^{5}$

Que as palavras que diriges aos que se encontram contigo sejam gentis, e sejam doces as maneiras de chamares as pessoas. Contudo: Respeito para com as mulheres! Olhar voltado para o chão!

Fala tudo de modo prudente, e transmite com a voz o que é útil, medindo a tua voz pela necessidade dos ouvintes, a ponto de ser audivel, não escapando da escuta dos presentes por estar muito reduzida, nem ficando exagerada com uma gritaria.

Cuida de que nunca fales aquilo que não averiguaste e refletiste com antecedência. Também não lances apressadamente as tuas palavras entre as do outro, pois é preciso em turnos ${ }^{6}$ escutar e falar, distribuindo no tempo palavra e silêncio.

Aprende com satisfação, e ensina sem inveja. Nunca escondas dos outros a sabedoria por causa de inveja, nem te abstenhas do aprendizado por vergonha. Submete-te aos presbiteros ${ }^{7}$ como aos pais. Honra os que cultuam a Deus. Sê tu o inaugurador da sabedoria e da virtude.

2 O título no manuscrito figura como K $\Lambda$ IMENTO $\Sigma$ ПАРАГГЕ $\Lambda$ MATA. A troca do $\eta$ por um $\iota$ na primeira sílaba do nome se deve a erro muito comum e foneticamente justificável.

3 Aqui, como em outros trechos, sigo a correção de editores, pelo fato da construção do manuscrito não se mostrar adequada semântica ou sintaticamente. Anoto as alterações mais relevantes. No presente

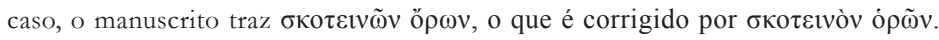

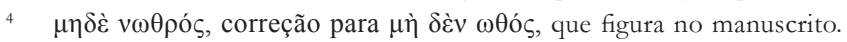

5 É significativo que, também em $O$ Pedagogo II, 11, o gesto da cabeça seja tratado junto com o modo do caminhar.

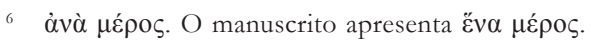

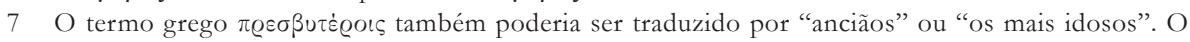
contexto, contudo, sugere que se pretende o sentido eclesiástico do termo.

$8 \quad x \dot{\alpha} \tau \alpha \varrho \chi \varepsilon$ pode indicar que se realize o início de algo, que se inicie o rito em que se oferece algo como sacrifício, ou que se governe algo. Em princípio, esses três sentidos são cabíveis em Clemente. Pelo contexto, entendo que o que se sugere é que o aluno Clemente não deve esperar que o outro demonstre primeiro virtude e sabedoria no relacionamento, mas ele mesmo precisa ser aquele que começa a interação com essa disposição. 
Não te apresses para junto dos amigos como um briguento, nem como um zombador contra eles ou um palhaço. ${ }^{9}$ Rejeita com veemência a mentira, a malícia e a insolência ${ }^{10}$. Mas, como ${ }^{11}$ um homem tranquilo e generoso ${ }^{12}$, suporta com linguagem positiva até mesmo $o$ arrogante e insolente.

Tudo que é teu - tanto obras quanto palavras - esteja disposto para Deus. E oferece todas as tuas coisas a Cristo. Volta a alma para Deus constantemente. E confia o pensamento ao poder de Cristo como se estivesse em um porto, a divina luz do Salvador, descansando de toda discussão e atividade.

À luz do dia, por um lado, compartilha com frequência teu próprio pensamento com as pessoas, por outro lado, mais ainda, compartilha-o com Deus tanto de dia quanto de noite igualmente. De tal modo, pois, que o sono não se apodere de muitas das preces $e$ hinos a Deus. Pois o sono duradouro é um rival à altura da morte. ${ }^{13}$ Como partícipe de Cristo, sempre te coloques sob o divino brilho que resplandece desde o céu. Com efeito, Cristo seja para ti um contentamento contínuo e incessante.

Não afrouxes o vigor da alma com festejo e relaxamento das bebidas. Antes, considera suficiente o necessário para o corpo. ${ }^{14} \mathrm{Não}$ te aproximes dos alimentos com avidez antes mesmo que tenha chegado o momento da refeição. E seja pão a tua refeição, e também estejam à mão ervas da terra e frutas da estação retiradas das árvores. Vai ${ }^{15}$ de encontro ao alimento com parcimônia ${ }^{16}$, e não manifestando uma gula enfurecida. Também não te lances como um carnivoro ${ }^{17}$ ou amante do vinho, quando alguma doença não levar a isso com vistas à sua cura. ${ }^{18}$

Não obstante, no lugar dos prazeres que há nessas coisas, toma as felicidades que estão nas palavras divinas e nos hinos, as quais ministram para ti com a sabedoria da parte de Deus; e uma reflexão celestial sempre te eleve em direção ao céu.

Faze cessarem as muitas preocupações a respeito do corpo, tendo colocado tua confiança nas esperanças para com Deus, porque te proverá as coisas necessárias: alimento

9 Em O Pedagogo 2,11, Clemente adverte contra conversas sem sentido, nas quais a pessoa difama outras com o propósito de fazer rir.

10 v̋ß̣ıs pode indicar também violência. No âmbito do trágico, é bem traduzido por "desmedida". Esse sentido transparece um pouco também em "insolência". O insolente desconhece ou desrespeita a medida de seu papel na interação.

11 ஸ́s é uma inserção, não figurando no manuscrito.

$12 \mu \varepsilon \gamma \alpha \lambda \dot{\alpha} \psi u \chi o \varsigma$, literalmente, "que tem grande(za de) alma".

13 O aparente exagero se torna mais compreensível à luz de O Pedagogo II, 9. O valor do homem adormecido é igualado ao do homem morto, marcadamente sua inutilidade.

14 Com relação às bebidas, a natural, moderada e necessária para o sedento é a água, segundo $O$ pedagogo II, 2.

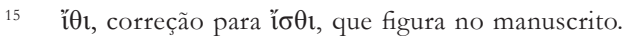

$16 \varepsilon \dot{\sigma} \tau \alpha \theta \tilde{\omega} \zeta$, correção para a lição do manuscrito, que apresenta $\alpha \sigma \tau \alpha \theta \tilde{\omega} \zeta$, praticamente o oposto do que foi traduzido, o que tornaria a instrução absurda.

17 Em O Pedagogo II, 1, o consumo de carnes aparece como uma concessão, e o teólogo sugere carne assada simplesmente. Muito semelhante era o conselho de Fílon em Sobre os Sonhos 2.49-50.

18 Clemente inicia o trecho de O Pedagogo sobre as bebidas (II, 2) citando 1 Tm 5.23. 
suficiente para a vida, o véu do corpo e proteção contra o frio invernal. ${ }^{19}$ Pois, decerto, de teu rei é a terra inteira e tudo quanto ela produz. E, como se da estrutura corporal dEle mesmo, cuida extremamente da de seus adoradores, exatamente como utensílios sagrados e templos dEle. Por isso, então, não tenhas medo de doenças abundantes, nem da aproximação no tempo da velhice que se espera. Pois cessará também a doença, quando, com firme propósito de alma inteira, pratiquemos os mandamentos dEle.

Sabendo disso, torna a alma forte para as doenças. Sê corajoso como um homem excelente nos estádios, para resistir às dores com o poder inflexivel. Não deixes a alma muito sobrecarregada por alguma aflição, se te oprime uma doença que te acomete, ou se sobrevém qualquer outra coisa desagradável, mas, de modo nobre, antepõe o pensamento às dores, elevando graças a Deus também em meio às coisas dolorosas, visto que Ele reflete sobre coisas mais sábias que as dos seres humanos, as quais, inclusive, não é possivel nem fácil para os seres humanos apreender.

Sê misericordioso para com os que sofrem adversidades ${ }^{20}$, e pede o socorro da parte de Deus para os seres humanos. Pois assentirá ao que pede a graça para o amigo, e proverá ajuda para os que sofrem adversidades ${ }^{21}$, querendo fazer notável o Seu poder entre os seres humanos, de modo que, vindo eles ao conbecimento, cheguem a Deus, e desfrutem da eterna bem-aventurança, quando perto estiver o Filho de Deus, restituindo as coisas boas aos que lhe são próprios.

\section{Referências bíbliográficas}

CLEMENT OF ALEXANDRIA. The exhortation to the greeks, the rich Man's salvation and the fragment of an address entitled to the newly baptized. Greek Text with an English Translation by G. W. Butterworth. Cambridge, MA: Harvard University Press, 1960.

CLEMENS ALEXANDRINUS. Protrepticus und Paedagogus. Preussischen Akademie der Wissenschaften von Otto Stählin. Leipzig: J. C. Hindrichs'sche Buchhandlung, 1905.

EUSEBIUS OF CAESAREA. The Ecclesiastical History. Vols. 1-2. Greek Text with an English Translation. London; New York; Cambridge (MA): Putnam's Press; Harvard University Press, 1926-1932.

FERGUSON, John. Clement of Alexandria. New York: Twayne Publishers, 1974.

MARROU, Henri-Irénée. Humanisme et christianisme chez Clément d'Alexandrie d'après le Pédagogue. In: MARROU, Henri-Irénée. Christiana tempora: mélanges d'histoire, d'archéologie, d'épigraphie et de patristique. Rome: École Française de Rome, 1978, p. 337-354.

PHILO OF ALEXANDRIA. Philo in ten volumes (and Two Supplementary Volumes). COLSON, F.H., WHITAKER, G.H. (trads.). London; Cambridge, MA: Heinemann; Harvard University Press, 1929-1962.

\footnotetext{
19 Em O Pedagogo II, 11, Clemente define a necessidade das roupas como sendo fundamentada em nada além do ocultamento o corpo - por isso, aqui, dizer-se "véu do corpo" - e da proteção contra o clima - ali, incluindo, além do frio, o calor.

20 O manuscrito traz $\varkappa \alpha \lambda$ oupévoเs, "aos que chamam" ou "aos que invocam". A tradução segue uma

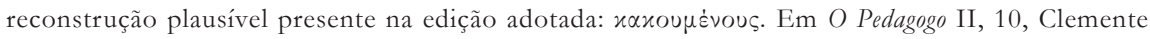
aponta como exercício adequado ao cristão o ato de dormir ao lado de um amigo doente, ajudar o cambaleante, e suprir as necessidades do carente.

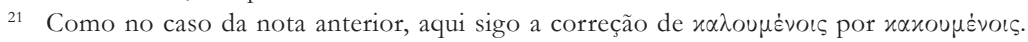

